AGNIESZKA TUROŃ

Instytut Nauk Politycznych i Dziennikarstwa UŚ

\title{
Poglądy społeczne Naphty jako diatryba na humanizm w Czarodziejskiej Górze Tomasza Manna
}

$\mathbf{M}$ istycy i matematycy poszukują tego, co niewytłumaczalne; tego, co nazwać można rzeczywistością ostateczną. Matematycy będą wypatrywać zasad logicznych, stanowiących ostateczną granicę świata fizycznego; mistycy - poszukiwać w Bogu ostatecznej granicy rzeczywistości duchowej. Próba zjednoczenia matematyki i mistyki przez pitagorejczyków, dla których zasady matematyczne stanowią arche, a świat został z nich ostatecznie zbudowany oraz posiadają one dla nich samodzielność egzystencjalno bytową; wydawałoby się była doskonała, lecz nie powiodła się, ponieważ ruch pitagorejski rozłamał się na dwie "gałęzie" - mistyczną i matematyczną. Próba_takiego połączenia byłaby dla empirycznego spojrzenia arystotelików aberracją, bo świata możemy doświadczać tylko w sposób realny, a zasady matematyczne stanowić mogą co najwyżej doskonałe narzędzie do jego opisywania. „A widzieć w nich - pisze Leszek Kołakowski - rodzaj rzeczywistości pierwotnej względem zjawisk fizycznych niczym innym jest, jak zabobonem”. Te dwie drogi, fatalnie „wichrowate”, wydają się całkowicie od siebie oddzielone; mistyk nigdy nie będzie zainteresowany wiedzą świecką, matematyk natomiast nigdy nie zdoła udowodnić, że jego zasady są natury absolutnej ${ }^{2}$. Mistycy nie konstruują racjonalnych rozważań, które wzniosą

L. Kołakowski, Mini-wykłady o maxi-sprawach, Kraków 2004, s. 103.

Tamże, s. 105. 
nas na wyżyny pojęć najistotniejszych, lecz zakładają Boga jako „fakt”, jako coś, co jest dane we wszechświecie na pewno. Jedna i druga droga zawieszają historyczną przypadkowość, ograniczenia czasowo-przestrzenne oraz niepewność kruchej, ludzkiej konstytucji, a wobec zasad logicznych albo Boga te realności stanowią tylko przejawy codziennego, ludzkiego doświadczenia. Moralność ludzi rozkłada się zatem na te dwie możliwe postawy - matematyka bądź mistyka.

Tomasz Mann pozostaje tutaj w zgodzie z zacytowanym L. Kołakowskim. On też nadaje określone rysy bohaterom Czarodziejskiej Góry, które L. Kołakowski nazwał umownie rysami dwóch postaw - „matematyka” i „mistyka". Z jednej strony, mamy racjonalistę i wolterianistę Settembriniego, $\mathrm{z}$ drugiej strony przeciwieństwo tych poglądów, skupiające się w postaci jezuity Naphty. Ponadto to właśnie ten bohater stanowi oddźwięk na wyzwanie, jakie rzucił bohater wspomnianego Musila. To Naphta konstatuje: „nauki przyrodnicze, nauki ekonomiczne nie pominęły nic, ale to nic, co mogło przyczynić się do poniżenia człowieka, zaczynając od astronomii, która z ośrodka świata, z dostojnej sceny, gdzie Bóg i szatan walczyli o upragnioną władzę nad stworzeniem, uczyniła małą planetę i na razie zniweczyła wspaniałą pozycję kosmiczną człowieka, na której nawiasem mówiąc, opierała się też astrologia" ${ }^{3}$. W sporze z Settembrinim uwidoczniony zostaje pogląd Naphty na konieczność podziału dobra i zła. Dla niego dualizm, antyteza jest czynnikiem, który wzmaga, pobudza, jest czymś namiętnym, pomysłowym. „Widzieć świat rozszczepiony na wrogie moce, oto duch. Wszelki monizm jest nudny. Solet Aristoteles quaerere pugnam"4; odpowiada Naphta na słowa Settembriniego, który zarzuca mu, „żądza przyjemności każe mu dzielić świat na dwie wrogie części, rozrywać Boga i przyrodę"5. W duchu klasycznego średniowiecza, na gruncie rozważań filozoficznych, okazuje się, że gdy substancjalność Arystotelesa przeniesie się na jednostki, istotę rzeczy z ogółów na zjawiska oraz zerwie się jedność świata z najwyższą ideą, to uwidacznia się jeszcze klarowniej rozdział - na Boga i świat pozaboski. Zwrócić należy szczególniejszą uwagę na znaczenie słowa „klasyczność”. Dla Naphty, to właśnie idea średniowiecza, nie antyku, jest klasyczna, bo to ona dosięga szczytu możliwości intelektualnych rozważań. Settembrini wskazuje tutaj jednak, że postawa Naphty, jego odróżnienie dobra i zła, pochwała dualizmu świata, wszelka antyteza jest związana z nihilizmem i nienawiścią, a nie z zasadą miłości bliźniego. To, co bohater R. Musila, według L. Kołakowskiego,

T. Mann, Czarodziejska Góra, przeł. J. Kramsztyk, t. 2, Wrocław 2004, s. 55.

Tamże, s. 35.

Tamże. 
odrzuca jako wrogie i niebezpieczne życiu ludzkiemu, jako konsekwencje rozróżnienia dobra i zła, powtarza T. Mann w Czarodziejskiej Górze właśnie słowami spierającego się z Naphtą Settembriniego oraz w ostatecznym rozrachunku autora ze swoim bohaterem, gdy na ostatnich stronnicach zapisana jest mu śmierć samobójcza.

Odróżnienie dobra i zła pozwala Naphcie oczekiwać, że przyszłość przyniesie daleko idące zmiany. „Czeka nas rehabilitacja scholastyki; jest ona w toku, Kopernik będzie pobity przez Ptolemeusza. Teza heliocentryzmu natrafia powoli w umysłach na opór, który zapewne doprowadzi do celu. Nauka okaże się filozoficznie zniewolona od tego, by Ziemi przywrócić wszystkie dostojeństwa, które dogmat kościelny chciał jej zapewnić" ${ }^{\text {; }}$ wypowiada Naphta. Odrodzenie, któremu zarzucał jezuita poniżenie ludzkiej jednostki, nie pozostawia $\mathrm{w}$ mocy przeciwieństwa Boga $\mathrm{i}$ świata, odrzuca autorytarnie transcendencję Boga wobec człowieka, która zezwala przez to na dyskryminację natury ludzkiej jako grzesznej i niższej aksjologicznie względem Boga i Kościoła. Zaprzeczając odrodzeniowej rehabilitacji człowieka w środowisku ziemnym $^{7}$, Naphta uwidacznia nie tylko koncepcję dychotomii między Bogiem a przyrodą, Bogiem a człowiekiem, ale także ukazuje dychotomię istniejącą w samym człowieku. „A i człowiek jest dwoisty w swym istnieniu: zagadnieniem jego duszy jest antagonizm pierwiastków zmysłowych i nadzmysłowych, a sprawy społeczne są na dalekim drugim planie. Jedynie taki indywidualizm mogę uważać za konsekwentny"; ; konstatuje Naphta. Kategoryczna niezgoda jezuity na brak świata nadzmysłowego, dualizmu, na pochłonięcie zaświatów przez doczesność, upadek przeciwieństwa Boga i przyrody; pozwala na zaprzeczenie renesansowych, a jeszcze wcześniej starożytnych rozważań o harmonii i jednolitości konstytucji człowieczej. Dla niego człowiek zawsze pozostaje miejscem zmagania się dwóch wrogich zasad.

Koncepcje dualizmu antropologicznego sięgają filozofii starożytnej. Dualistyczna relacja między ciałem a duszą widoczna jest w Platońskiej filozofii, która przybrała nowy, ascetyczny charakter moralności, a przejęta przez neoplatoników i św. Augustyna stanowiła podwaliny klasycznego średniowiecza. Naphta podkreśla, ,jeśli filozofii Platońskiej dawano pierwszeństwo przed wszelką inną, to dlatego że zajmowała się nie poznaniem przyrody, lecz poznaniem Boga”. „Do koncepcji relacji zachodzących między duszą

Tamże, s. 56.

W. Ullman, Średniowieczne korzenie renesansowego humanizmu, przeł. J. Mach, Łódź 1985, s. 137.

8 T. Mann, Czarodziejska Góra, s. 57.

9 Tamże. 
i ciałem oprócz składnika metafizyczno-ontologicznego dochodzi religijny składnik orfizmu, który strukturalne rozróżnienie między duszą (= nadzmysłową) i ciałem (= zmysłowym) przekształca w strukturalna opozycję"10; pisze Giovanni Reale. Ciało zdaje się spełniać w tym związku rolę drugorzędną, jest sokratejskim grobem dla duszy, zawdzięcza swoje życie i uzdolnienia duszy, a jego zadanie sprowadzić można do pojemnika, który dusza może wypełniać. Czytamy w Platońskim Gorgiaszu, „i nie dziwiłbym się, gdyby słowa Eurypidesa zawierały prawdę, gdy mówi: Kto wie, czy życie nie jest umieraniem,/ Śmierć zaś życiem?/ I może tutaj jesteśmy nieżywi; jak słyszałem jednego z mędrców mówiącego, że my teraz umarliśmy, a ciało jest naszym grobem [...]"11. Określając konstytucję człowieka, można dokonać pewnej analogii; można powiedzieć, że substancjalność człowieka, ciało, związane jest z pierwszym poziomem rzeczywistości, z poziomem, na którym dostrzegamy to, co zmysłowe; natomiast duszę związać można z tym, co inteligibilne, $z$ tym, co jest przedmiotem intelektu oraz niecielesne, odrywając zupełnie od świata materialnego.

Jak pisze W. Witwicki, „nie ma powodu barbaryzować życia i na tym punkcie - wystarczy, w myśl złotych wierszy pitagorejskich, miarę zachować we wszystkim"12. I w tym momencie drogi intelektualne bohatera Czarodziejskiej Góry i spuścizny filozoficznej, do której tak gorliwie się odwołuje, rozchodzą się. Naphta zapalczywie wygłasza swoje ascetyczne poglądy, i daleko mu do pitagorejskiego umiaru. Przeciwnie w swoim poglądzie na dualistyczną relację dusza-ciało wykazuje się skrajną nietolerancją względem ciała ludzkiego, które nie tylko można, ale i należy zadręczać. „Bo ropiejące wrzody ciała stawiają przed oczy nie tylko jego upadek, ale także odpowiadają jadowitemu zepsuciu duszy, i to w sposób budujący i budzący duchowe zadośćuczynienie - podczas gdy rozkwit ciała zwodzi tylko i obraża sumienie, więc też w najwyższym stopniu słusznie chciano go wyprzeć, schylając czoło przed ułomnościami”"13, konstatuje Naphta. Platon poszukiwał czystości w rozumie i to jemu przypisywał autarkiczny charakter, natomiast Naphta, jako pilny uczeń klasycznego średniowiecza, upatruje tej czystości w wierze. Quis me liberabit de corpore mortis huius? To jest głos prawdziwej ludzkości dla jezuity, dla którego godność człowieka nie tkwi w ciele, lecz duszy i to w dodatku w takiej, która jest skłonna unikać rozkoszy życiowych. Naphta rozszerza swoje poglądy o udręczaniu ciała i jego pozytywnych skutkach dla zbawienia ludzkiej duszy. Człowiek sam powinien zadawać cierpienie ciału,

\footnotetext{
G. Reale, Historia filozofii starożytnej, przeł. E. I. Zieliński, t. 2, Lublin 2001, s. 242. Platon, Gorgiasz, 492e, przeł. P. Siwek, Warszawa 1991.

W. Witwicki, Objaśnienie tłumacza, s. 495.

T. Mann, Czarodziejska Góra, s. 110.
} 
by z powrotem ster naszego życia mogła objąć dusza. Natomiast jeżeli nie potrafi sam tego czynić, powinien przyjmować kary od tych, którzy walczą o jego duszę.

Miejscem ośrodkowym poglądów Naphty pozostaje nie tylko „ułomność" (według jego mniemania) prawa w Europie Zachodniej, których fundamentów intelektualnych i światopoglądów poszukuje w silnie krytykowanej, humanistyczno-oświeceniowej doktrynie; ale zakres jego poglądów skupia się przede wszystkim na ułomności ludzkiej jako takiej. Jak zauważa L. Kołakowski, „miejscem interesowności była ułomność i nędza ludzka lecz nie ta naoczna, widoma bezpośrednio, uleczalna, ale ułomność fundamentalna, nie dająca się przezwyciężyć środkami technologicznymi, inwalidztwo samego istnienia, które, skoro raz zostało tak czy owak zrozumiane, podsuwało sugestię, iż jest właściwym sprawcą empirycznej, namacalnej ułomności, a ta ostatnia - wtórnym jej przejawem"14. Przyrodzona ułomność w filozofii chrześcijańskiego średniowiecza przejawiała się ludzką „przypadkowością" i zasadniczą nierównością między Bogiem (tożsamość istoty i istnienia) a człowiekiem (odróżnienie istoty od istnienia). Ta przygodność bytu skończonego i śmiertelnego skłania człowieka wiary chrześcijańskiej do pokory i uwielbiania Boga. Tradycja platońska (do której sięga św. Augustyn, średniowieczna doktryna Ojców Kościoła, a tym samym i bohater Czarodziejskiej Góry, Naphta) z tej specyficznej, ludzkiej okoliczności uczyniła największą niedoskonałość człowieczeństwa. „Ale nie-być-tym-czym-się-jest to cierpieć na nieznośne rozdwojenie, to żyć ze świadomością upadku własnego, to tęsknić nieustannie do doskonałej identyfikacji, której życie fizyczne, wystawione na zagładę, życie w czasie żadna miarą zapewnić" ${ }^{15}$, pisze L. Kołakowski.

Choroba jest dla jezuity z Czarodziejskiej Góry nieodłącznym atrybutem każdej ludzkiej jednostki. Choroba jest tożsama z człowiekiem tak bardzo, że nie można dopuścić do siebie żadnej innej formy człowieczeństwa niż to, które oczekuje w zbawieniu uzdrowienia, a w doczesności piętnuje człowieka grzechem i wymusza na nim odwieczną pokorę wobec transcendencji. Człowiek jest niewolnikiem i jedyne, co mu pozostaje, to skrupulatnie wypełniać nakazy i obowiązki wypływające z doktryny kościelnej. Takiego człowieka pozbawia się jego naturalności poprzez chrzest, a odrodzenia oczekuje się w łasce zbawienia. „W samej rzeczy człowiek z istoty swojej jest chory. Właśnie choroba „robi” go człowiekiem - a wszyscy ci, co usiłują go uzdrowić, co chcą go skłonić do pogodzenia się z naturą, do powrotu do natury (choć on na-

14 L. Kołakowski, Główne nurty marksizmu, t. 1, Poznań 2000, s. 22.

15 Tamże, s. 23. 
prawdę nigdy do niej nie należał), [...] wszystkie te odmiany Rousseau prowadzą tylko do odczłowieczenia i zezwierzęcenia..."16 - określa Naphta. Humanistycznych haseł, takich jak „ludzkość” i „dostojność” upatruje właśnie w człowieku oderwanym od natury, w takiej jednostce, która czuje się jej przeciwieństwem; od życia organicznego odróżnia go duch. Przedstawia chorobę i śmierć jako najwyższe dostojeństwo człowieka; zdrowie i życie jako coś niecnego. „Więc też w duchu - mówi Naphta - w chorobie leży jego godność i dostojność; jednym słowem, jest on tym bardziej człowiekiem, im bardziej jest chory; i geniusz choroby jest czymś bardziej ludzkim niż geniusz zdrowia" ${ }^{17}$.

T. Mann w eseju Goethe i Tołstoj, [czyli] przyczynki do problemu humanizmu pisze: „Problem ARYSTOKRATYZMU sprowadza się do kwestii, czy ta ISTOTA nie jest tym bardziej CZŁowIEKIEM, im skuteczniej oderwała się od natury, czyli im bardziej jest chora. Bo czym jest choroba, jeśli nie stanem odcięcia od natury?"18. Autor Czarodziejskiej Góry odnosi tę myśl do stanu chorobowego, w jaki popadł Tołstoj, stanu, który związany był ze swego rodzaju obłędem mistycznym (jak określił ten stan francuski krytyk Vogüé). W portrecie Lwa Tołstoja można dopatrzyć się zasadniczej zbieżności w przedstawionych przez T. Manna poglądach na temat przezwyciężenia natury, jako skutku mistycznego szaleństwa rosyjskiego pisarza, a późniejszym włączeniu takich samych myśli bohaterowi Czarodziejskiej Góry, Naphcie. Tołstoj wymaga oderwania się od natury, ponieważ człowieczeństwo oznacza dla niego porzucenie tego wszystkiego, co ma podstawy w zmysłach i instynktach. Wymaga ascetycznego wręcz przezwyciężenia cielesności i zmysłowości, jako najlepszego sposobu odnalezienia człowieczeństwa. „UCZUCIE KRZYŻA, do którego niesienia każdy z nas jest powołany" ${ }^{19}$, przywołuje słowa Tołstoja T. Mann. Znaczenie słowa „krzyż” określa postawę rosyjskiego pisarza i znaczący proces u każdego człowieka, by oderwać się wreszcie od natury. Kilka lat później na stronnicach swej powieści T. Mann powtórzy takie poglądy na potrzebę oderwania się od natury i potrzebę noszenia krzyża na barkach każdego człowieka, jako powinności moralnej. Myśli Tołstoja wyrazi w swoich radykalnych poglądach Naphta, dla którego wszystko, co związane ze zmysłowością, będzie potępione, a cielesność będzie przypominać człowiekowi o jego wrodzonym grzechu i powinności dążenia do zbawienia. Dla T. Manna próba dążenia do wynaturzenia i odnalezienia swego człowieczeństwa tylko w sfe-

T. Mann, Czarodziejska Góra, s. 120.

Tamże.

18 T. Mann, Goethe i Tołstoj - przyczynki do problemu humanizmu, w: tenże, Dostojewski $z$ umiarem $i$ inne eseje, przeł. J. Błoński i inni, Warszawa 2000, s. 113.

19 Tamże, s. 115. 
rze duchowej, nieskalanej piętnem namiętności i zmysłowości stanowi przyczynę wszelkiej choroby.

Odpowiednią konstatację stanowią słowa Naphty, „mówił wtedy o dos bonderos, czyli dwóch sztandarach, pod którymi skupiają się do wielkiej wojny dwie armie, armia piekła i armia duchowa: druga z nich pod Jerozolimą, gdzie wszystkimi dobrymi dowodzi Chrystus, ich capitan general, a pierwszy na równinach Babilonu, gdzie Lucyfer występuje jako caudillo, czyli herszt..." ${ }^{20}$. O ile dla Naphty szatańskie moce objawiać się będą na włoskich ziemiach, na których powstają fundamenty pod koncepcje, które pragną po latach ciemności i hibernacji człowieka naturalnego dokonać jego rehabilitacji, o tyle dla Settembriniego diabelskie siły próbują odrodzić szlaki inkwizycji, które podeptały ludzką godność w imię łaski zbawienia. 0 tyle również dla Naphty niebiańskie obszary otwierają się tam, gdzie człowiek uświadamia sobie, że hierarchia bytów nie stanowi o jego tragicznym umiejscowieniu, lecz przeciwnie - utwierdza go w odpowiedniości tegoż miejsca, z racji piętna, jakim jest grzech mu przypisany od narodzenia. A jego człowieczeństwo opierać się powinno z najwyższym pietyzmem o dogmaty i prawdy wiary niepodważalne. O tyle dla Settembriniego anielskie chóry zaczną śpiewać, gdy człowiekowi zwróci się jego dostojeństwo w postaci jednostki, której przywraca się istotę niezależną od chrztu i łaski.

Odróżnienie dwóch porządków rzeczy, dążenie do rozpowszechnienia nauki opartej o zasadę podziału świata na ten grzeszny, naturalny, czyli padół ziemski oraz na ten nieskazitelny, transcendentalny, czyli niebiańskie przestworza - to koncepcje, które identyfikujemy z główną myślą klasycznego średniowiecza. „Zatem, jak się wydaje, w paralelizmie tych dwu bibliotek konkretyzuje się specyficzny aspekt teoretyczno-kulturowy, jedna z licznych form powracającego dualizmu, też korzeniami tkwiącego w platonizmie, typowego dla średniowiecznego chrześcijaństwa: dualizmu duchowości i fizykalizmu, duszy i ciała, bytu (niezmiennego, formalnego, powszechnego, wiecznego) i materii (zmiennej, przypadłościowej, partykularnej, podlegającej zmianom w czasie), państwa Bożego i państwa człowieka"21, pisze Giulio d'Onofrio.

W tym kontekście nie trudno zauważyć, że jezuita z Czarodziejskiej Góry, będzie przedstawicielem poglądów klasycznego średniowiecza. Naphta w rozważaniach intelektualnych „wieków średnich” poszukuje źródeł prawdy o człowieku, świecie i społeczeństwie. Przedstawiciele renesansowego

20 T. Mann, Czarodziejska Góra, t. 2, s. 104.

21 G. d'Onofrio, Historia teologii, przeł. W. Szymona, t. 2, Epoka średniowieczna, Kraków 2005, s. 27. 
spojrzenia na świat odnoszą się pogardliwie i lekceważąco do tych czasów, nazywając je mrokami nocy, która panowała przez 1000 lat. Również pejoratywnie określa się, panujący wtedy ruch w sztuce - „stylem gotyckim”, jako że Gotowie byli plemieniem barbarzyńskim. Naphta w swoim pokoju umieszcza w drzewie rzeźbę stanowiącą wizerunek męki Chrystusowej. $\mathrm{Z}$ dumą przedstawia ją jako wytwór gotyckiego średniowiecza, które nic nie upiększa, nie oszczędza widza, bez niepotrzebnych detali opisuje cierpienie i słabość ludzkiego ciała, ze wzniosłością dodaje, że styl gotycki jest kwintesencją pesymizmu i ascezy, które wyznaje. Ponadto wyznacznikiem odpowiedniości, wyznawanej ideologii, jest to, że rzeźby, obrazy, dzieła nie były własnością indywidualnej jednostki, nie poszukiwano oryginalności, lecz poszukiwano prawdy, stąd też dzieła były anonimowe. „Pietá, prymitywna a wyrazista aż do groteskowości: Matka Boska, w czepcu, ze ściągniętymi brwiami, z otwartymi od jęku wykrzywionymi ustami, a na jej kolanach martwe ciało Chrystusa, ciało o nieudolnych proporcjach, o wyjaskrawionej a nieumiejętnej anatomii, z opuszczoną głową w cierniowej koronie, z twarzą i kończynami z krwią poplamionymi i zbroczonymi, z grubymi gronami skrzepłej krwi”"22, opisuje T. Mann.

Krytyka doktryny chrześcijańskiego średniowiecza wypływa nie tylko z powodu rozróżnienia w człowieku i świecie dwóch przeciwstawnych pierwiastków: zmysłowego-nadzmysłowego oraz nadania mu pewnych wartości (pierwsze są niższe, drugie są wyższe), lecz przede wszystkim za skutki takiej skrajnej doktryny, która jest w stanie usprawiedliwić w imię wyznawanego podziału nieludzkie okrucieństwo, nietolerancję, poniżenie, jak również potrzebę traktowania człowieka „mieczem i stosem”. „Miłości tej służyła maszyneria - zauważył Naphta - za pomocą której Konwent oczyszczał świat ze złych obywateli. Wszelkie kary kościelne, nawet stosy, nawet ekskomunika były ustanowione, aby duszę ratować od wiecznego potępienia, czego nie można powiedzieć o niszczycielskiej żądzy jakobinów. Pozwalam sobie zauważyć, że wszelka sprawiedliwość, operująca torturą i krwią, i JEŚLI NIE WYPŁYWA Z WIARY W ŻYCIE POZAGROBOWE [podkr. A. T.], jest bydlęcą niedorzecznoŚcią" ${ }^{23}$.

Dla Naphty człowiek jest miarą rzeczy, a stan ten uzależniony jest od zbawienia, które stanowi kryterium prawdy. Czyste teoretyczne poznanie nie istnieje, ponieważ w mocy pozostaje dewiza św. Augustyna, że wiara to możliwość poznania. „Wiara jest narzędziem poznania, intelekt ma charakter wtórny [...] zawsze jest w nauce jakaś wiara, jakiś pogląd na świat, jakaś

T. Mann, Czarodziejska Góra, t. 2, s. 52.

Tamże, s. 55. 
idea, krótko mówiąc, jakaś wola - a rzeczą rozumu jest wolę tę zanalizować i wykazać. Wszystko i zawsze zmierza ku jednemu: ku quod erat demonstrandum" "24; mówi Naphta. Poznanie bez związku z ideą łaski i zbawienia jest poznaniem nieprawdziwym. Już od filozofii Platońskiej, na którą powołuje się jezuita, poprzez filozofię św. Augustyna, którą sobie ceni, okazywano pierwszeństwo temu, co zajmowało się poznaniem tego, co transcendentne, poznaniem Boga. „To dziecinne sądzić, że Kościół bronił ciemności przeciw światłu. Po trzykroć słusznie za karygodne uznał dążenie do poznania rzekomo nieuprzedzonego, to znaczy takiego, które pomija potrzeby duchowe i sprawy zbawienia; tym, co w ciemności wtrąciło człowieka i coraz głębiej wtrącać go tam będzie, jest właśnie to nieuprzedzone, afilozoficzne przyrodoznawstwo" 25 , mówi Naphta. Ponadto, powiązanie poznania teoretycznego z ideą zbawienia określa bardzo wyraziście średniowieczną koncepcję, która pozbawia filozofię niezależności i samodzielności, a w zadawaniu pytań i podejmowaniu polemiki odznacza się jednostronnością, która wynika z jej podporządkowania teologii. Filozofia ma systematyzować niewzruszone prawdy wiary oraz nie może zaprzeczać temu, co teologia uznaje za prawdziwe.

W sporze z Settembrinim, jego oponent wykazuje wspólną drogę i moment, w którym ich drogi rozchodzą się. Fundamentem obu światopoglądów jest wiara w stan przednaturalny, który był stanem idealnym, bez krzywd, różnic klasowych, bez przymusu, bez związków cielesnych (tylko z tym ostatnim nie zgodził się humanista). Naphta zasadniczą ich zgodę sprowadza do pierwotnego, rajskiego stanu ludzkości, który związany był dla niego bezpośrednio z Bogiem, stan, który utracono przez grzech pierworodny. Nawet w istnieniu umowy społecznej (co wywołuje radość racjonalisty) jest w stanie dopatrzyć się wspólnych podstaw, mianowicie - uznanie grzechu i próba obrony przed krzywdami. Tutaj drogi oponentów rozchodzą się, ponieważ Settembrini wszelką władzę przekazuje ludowi oraz państwu. Natomiast Naphta nadaje państwu charakter boży, wyprowadza prymat Kościoła nad świeckim państwem. Państwo nie powstaje z woli ludu, lecz ustanowione zostało przez Boga, dlatego przejawia swój szatański charakter i jest wcieleniem zła oraz grzeszną niedoskonałością. „Że duszą jego jest pieniądz, [...] starożytność była kapitalistyczna, bo pełna uwielbienia dla państwa. Średniowiecze chrześcijańskie przejrzało immanentny kapitalizm świeckiego państwa"26, wykrzykuje jezuita. Identyfikuje on ideologię mieszczańską

$\begin{array}{ll}24 & \text { Tamże, s. } 56 . \\ 25 & \text { Tamże, s. } 57 . \\ 26 & \text { Tamże, s. } 60 .\end{array}$ 
z demokracją, zasadą narodowego państwa, z państwem powszechnym pod sztandarem kapitalistycznej republiki. On jednak nawołuje do powrotu czasów Grzegorza Wielkiego, do powrotu Państwa Bożego. Taka dyktatura miała być tylko środkiem, formą pośrednią między państwem pogańskim a królestwem niebieskim. Naphta przeciwstawia się humaniście; Kościół nie jest opiekunem ciemnego konserwatyzmu i kwietyzmu, a przyszłość nie zmierza ku ze zmianom i przewrotom opartym o siły kultury starożytnej, odrodzeniowej i oświeceniowej. Dla humanisty Kościół tłumił przez sąd inkwizycji i stosy wszelkie życiodajne myśli. ,Jeśli przez usta swych emisariuszy wypowiada się za przewrotem, to dlatego, ze celem jego jest stworzenie dyktatury motłochu i barbarzyństwa na gruzach wolności, kultury i demokracji" ${ }^{27}$, wykrzykuje Settembrini. Dla jezuity Kościół stanowi najdoskonalszą potęgę, najdostojniejszą kolebkę życia, ponieważ związana jest ona tylko z transcendentnym Bogiem i obszarem spraw duchowych. Z motłochem mamy do czynienia wtedy, gdy skrycie bądź jawnie występujemy wrogo przeciwko idei religijnej; gdy popieramy instynkty świeckie; te, które przeciwstawiają się idei ascetycznej w imię kobiety, wina, śpiewu, poezji. „[...] Kościół, będąc ucieleśnieniem idei religijno-ascetycznej, żadną miarą nie może popierać istniejących instytucji, nauk świeckich i państwowych norm prawnych, że, przeciwnie na jego sztandarze wypisane były zawsze hasła najradykalniejsze, hasła całkowitego przewrotu"28, pisze T. Mann słowami Naphty. Wszelkie hasła świeckiego świata, który jezuita identyfikuje z konserwatyzmem, mieszczaństwem, tchórzostwem i słabością, takie jak rodzina, państwo, sztuka, nauka pozostają w sprzeczności z ideą religijności. „Którego wrodzoną tendencją i nieodmiennym celem jest rozsadzanie istniejącego świeckiego porządku rzeczy i kształtowanie na nowo społeczeństwa według wzorów idealnego, komunistycznego Państwa Bożego"29, określa Naphta.

Walka Naphty z humanizmem Settembriniego nie sprowadza się tylko do znaczącej krytyki wiary w rozum i postępową naukę; to nie tylko zarzut braku duchowych (chrześcijańskiego średniowiecza) fundamentów, to przede wszystkim wiara w powrót na deski teatru XX wieku takiej duchowej koncepcji, która z całym swoim radykalizmem odrzuci panujący nowoczesny humanizm. „Krytykując światopogląd Settembriniego, Naphta wytyka mu, że jego humanizm jest owocem burżuazyjnego sposobu myślenia nacechowanego tchórzostwem, egoizmem, kultem pieniądza i ograniczonością per-

Tamże, s. 240.

Tamże.

Tamże. 
spektyw, jak również nieznajomością natury ludzkiej"30 - pisze Cezary Rowiński. Zaskakująca zdaje się być odpowiedź Naphty na pytanie o siłę, która będzie powodem upadku epoki humanizmu i jej ideałów. Taką siłę ma stanowić proletariat. „Wedle tego niedoszłego jezuity rewolucyjny proletariat nie robi nic innego, jak tylko kontynuuje dzieło ojców Kościoła, którzy potępiali handel, lichwę, nadmierne zyski, zdobywanie fortuny bez pracy, którzy sprzeciwiali się spekulacjom finansowym i manipulacjom ludzką pracą" ${ }^{31}$, pisze C. Rowiński. Komunizm istnieje jako ta doktryna społeczna, która próbuje przezwyciężyć ekonomizm, a której zasady i cele są takie same jak Państwa Bożego. „Ojcowie Kościoła mówili, że «moje» i «twoje» są zgubnymi wyrazami, a własność prywatna jest przywłaszczeniem i kradzieżą"32, mówi Naphta. Grzech pierworodny sprowadził na człowieka chęć posiadania ziemi, która w pierwotnym zamyśle jest własnością wszystkich ludzi, i prawo boskie nakazuje jej owoce rozdzielać według zasady „wspólnego użytkowania”. Posiadanie dóbr ziemskich wiąże się z grzechem chciwości, który doprowadził do powstania własności prywatnej. Ojcowie Kościoła wykazywali niechęć do handlu; a działalność gospodarcza stanowiła szkodę dla zbawienia ludzkości. Pieniądze przyrównywali do paliwa ognia piekielnego, podstawowe zasady ekonomii traktowali z pogardą z powodu znacznego wyzysku bliźniego. Największą zgrozą jednak napawało wyzyskiwanie czasu (tego powszechnego, boskiego urządzenia), gdy jeden człowiek nic nie robił i otrzymywał za to „rekompensatę” pieniężną, drugi natomiast zyskiwał tylko szkody za wykonany wysiłek. „Istotnie - kontynuował Naphta - te prawdziwe ludzkie duchy uważały myśl o samoczynnym mnożeniu się pieniądza za wstrętną [...] ludzie ci twierdzili, że każdy bogacz jest złodziejem bądź spadkobiercą złodzieja [...] uważali, jak Tomasz z Akwinu, handel w ogóle [...] za haniebne zajęcie. Pracy samej przez się nie byli skłonni cenić bardzo wysoko, jest bowiem sprawą moralną, a nie religijną, dokonywaną w służbie życia, a nie Boga" ${ }^{33}$.

Proletariat idee ludzkości i Państwa Bożego przeciwstawia burżuazyjno-kapitalistycznej doktrynie. Dyktatury proletariatu domagają się czasy, które potrzebują „zbawienia” politycznego, gospodarczego, ale przede wszystkim wzbudzenia grozy przed zbawieniem świata i dla osiągnięcia bezpaństwowego i bezklasowego synostwa bożego. Chrześcijański komunizm neguje technikę, maszynę, postęp, handel, wartość pieniądza; jednocześnie dla humanisty neguje wolność i osobowość, pociągając za sobą brak godności

30 C. Rowiński, Spór Naphty z Settembrinim, w: R. Dziergwa, Tomasz Mann w krytyce i literaturze polskiej, Poznań 2003, s. 311.

Tamże, s. 312.

32 T. Mann, Czarodziejska Góra, t. 2, s. 61.

33 Tamże. 
jednostki ludzkiej. Powrót do średniowiecznego powiązania z ziemią i brak zgody na prywatne posiadanie tej ziemi, prowadzi do czasów niewolnictwa i poddaństwa.

„Gramy na świecie moralną komedię, poddani ślepemu działaniu instynktów, interesów, potrzeb; to, co nazywa się życiem duchowym, zajmuje w niej dużo miejsca, ukrywając przed nieświadomymi aktorami te motywy za zasłoną usprawiedliwień i prestiżu" ${ }^{\prime 3}$, pisze Emmanuel Mounier. Jeden z twórców doktryny personalizmu, jako próby połączenia socjalizmu i chrześcijaństwa, konstatuje podobnie do bohatera Czarodziejskiej Góry, że w stosunkach świata duchowego (u Mouniera osobowego) ze światem natury nic nie ma przypomina swoim kształtem harmonii Lebnitza. Materia nie pozostaje tylko bierna, ale zaczyna przybierać charakter ofensywności. „Wszędzie, gdzie osoba wnosi swoje światło, natura, ciało albo materia przeciwstawiają swoją nieprzejrzystość, [...] wszędzie, gdzie wolność rozwija swój lot, zostaje obciążona tysiącem więzów, [...] wszędzie, gdzie ma się wyrazić intymność, wkrada się uzewnętrznienie, wystawienie na pokaz, uogólnienie: widomą ich cechą jest osłabienie przeżycia, jak pieniądz niesie ruinę życiu" ${ }^{35}$, konstatuje E. Mounier.

W świetle tych rozważań można zauważyć zbieżności dwóch prób połączenia ze sobą wydawałoby się odrębnych doktryn społecznych. Naphta potrzebuje proletariatu do tego, by w radykalny sposób przezwyciężyć świat za pomocą panowania nad światem, by przezwyciężyć ten świat siłą proletariatu pod znakiem krzyża; a takie poglądy stanowią melanż obskurantyzmu i dwuznacznej rewolucyjności ${ }^{36}$. Myśliciel francuski natomiast pragnie połączyć ze sobą dwa odmienne światy w zupełnie inny sposób. Dostrzega nie tylko braki w indywidualizmie (dla którego pierwszą troską będzie zwrócenie uwagi jednostki na siebie; natomiast jego personalizm dąży do ustawienia jednostki w otwartej perspektywie na drugiego człowieka) oraz niebezpieczeństwa w niecierpliwym optymizmie złudzenia liberalnego, ale dostrzega także niebezpieczeństwo w radykalnych i równie niecierpliwych koncepcjach pesymizmu faszystów. Jego połączenie doktrynalne nie stawia sobie za cel panowania i zwiększenia mocy działań, zmierzających do powrotu mentalnego czasów największej potęgi Państwa Bożego i dyktatury proletariatu. Jego próba to pogodzenie odwiecznego problemu między dychotomią świata naturalnego i duchowego w sposób jak najmniej radykalny. Osoba jest przede wszystkim czymś wewnętrznym, stwierdzi twórca personalizmu

34 E. Mounier, Wprowadzenie do egzystencjalizmów, przeł. E. Krasnowolska, Kraków 1964, s. 25.

35 Tamże, s. 32.

36 C. Rowiński, Spór Naphty z Settembrinim, s. 312. 
za Naphtą, ale doda zaraz, że potrzebuje on wyjścia poza wewnętrzność. „Nie trzeba gardzić tak bardzo życiem zewnętrznym: bez niego życie wewnętrzne stawałoby się szaleństwem, podobnie jak ono bez życia wewnętrznego zmierzałoby do bezsensu" ${ }^{37}$, pisze E. Mounier. Naphta zwraca uwagę na wspólną krytykę doktryny kościelnej i socjalistycznej, zwróconej w stronę współczesnych zasad ekonomizmu. Próba złączenia tych doktryn, to zgromadzenie podwójnej siły i radykalizmu dwóch nurtów myślowych, by wygrać z ówczesną doktryną racjonalizmu i indywidualizmu liberalnego. E. Mounier natomiast, połączenie to rozpatruje w kategorii dialektycznego związku, w wyniku którego obydwa człony (świata zewnętrznego i wewnętrznego) stanowią konieczną postawę funkcjonowania jednostki w świecie. „Myśl marksistowska, według której misją człowieka jest podniesienie godności rzeczy poprzez humanizację natury, jest tu bliska myśli chrześcijańskiej. [...] Centralna wartość, którą u Marksa staje się praktyczna działalność człowieka (praxis), jest pewnego rodzaju laickim odpowiednikiem centralnej wartości, którą jest praca w tradycji chrześcijańskiej" ${ }^{38}$, konstatuje E. Mounier.

Naphta oczekuje w świecie XX wieku nowej, jeszcze dotychczas nieznanej rewolucji, której naczelne hasło stanowić będzie zniewolenie jednostki w imię wyższych ideałów, co będzie paradoksalnie dla jego doktryny stanowiło jej wyzwolenie. Przeciwnik liberalizmu i humanizmu upatruje w przyszłej pedagogice bezwzględnych nakazów, żelaznej dyscypliny, samozaparcia, gwałtu na indywidualnej wolności oraz największej rozkoszy młodzieży: posłuszeństwa. To, czego od zawsze potrzebują jednostki ludzkie, przede wszystkim te młode (jeszcze nieukształtowane intelektualnie, bez określonych postaw do życia), i to, co zostanie im stworzone z połączenia ideałów i sił drzemiących w proletariacie i Państwie Bożym, to największe pragnienie, do którego zmierza ludzkość - terror. Świat Naphty oparty jest na wspomnieniach i chęci powrotu do średniowiecznych czasów, gdy zakonnicy z jednej strony uprawiali pełną ascezę, z drugiej strony - dla ustanowienia Państwa Bożego i panowania sił nadprzyrodzonych - nie cofali się przed rozlewem krwi oraz upatrywali w walce na śmierć $\mathrm{z}$ niewiernymi w imię ran Chrystusowych - zasługi dla chwały zbawienia. Inkwizycja zrodziła się dla niedoszłego jezuity absurdalnie z racjonalizacji. Nie liczono na Boga i jego wystąpienie w imię prawdy, lecz zmierzano do tego, by prawdę o winie wydobyć od oskarżonego. Sposobem na złamanie złego ducha było zwrócenie się do nędznej części człowieczej, ciała. Tortury zatem stawały się

37 E. Mounier, Wprowadzenie do egzystencjalizmów, s. 57.

38 Tamże, s. 39. 
niezbędnym narzędziem, by wydobyć prawdę zniewoloną przez diabolicznego ducha.

Próba połączenia racjonalizacji z powstaniem inkwizycji to cios wymierzony w Settembriniego jako ojca oświeconego humanizmu. Rozum staje się w tym wymiarze wynalazcą okropności, czemu Włoch się sprzeciwia, poszukując przyczyny w rozprzestrzenianiu przez ,średnie wieki” wiary w istnienie piekła oraz ascetyczne szaleństwo, że złoczyńcy tylko pomagają biednej duszy wydobyć jej prawdę, torturując ciało. „W działaniu, w czynie, mówił, istotnie panuje zdeterminowanie, nie ma w nim wolności, natomiast jest ona w bycie. Człowiek jest taki, jakim chciał być i jakim aż do swej zagłady nie przestanie chcieć być: jeśli nad życie pragnął mordować, to płacąc życiem, nie płaci ceny zbyt wysokiej. Niech umiera, bo pokutuje za największą RozKosz [podkr. A T.]" ${ }^{39}$, mówi Naphta. Morderca nie powinien żyć dłużej od zamordowanego, dodaje jezuita, bo połączeni są oni od tego momentu tajemnicą, którą według niego przyrównać można do tajemnicy między kobietą (istota bierna) i mężczyzną (istota czynna) w splocie miłosnym. Drwinę przejawia wobec postawy lęku przed krwią u przyjaciół ludzkości, a kult życia identyfikuje pogardliwie z mieszczaństwem i tchórzostwem w oczekiwaniu na nadejście czasów idei ponadindywidualnej i ponadosobowej, która będzie bez wahania poświęcać jednostki. „Naphta jest nie tylko śmiertelnym wrogiem tradycji humanistycznych i oświeceniowych, ale równocześnie reprezentantem kiełkującej wówczas w Europie nowej formy reakcji - faszyzmu. Głosi fanatyczne idee nienawiści i totalnego zniszczenia, jest zwolennikiem immoralizmu, przyznaje priorytet ciemnym instynktom"40, pisze Norbert Honsza.

Przedstawicielem świata, który odchodzi, jest humanista Settembrini; świat, który nadchodzi, napawa autora Czarodziejskiej Góry strachem, pogardą i grozą. Klimat nadchodzącej epoki związany jest z określonymi pierwiastkami filozoficznymi, ideologicznymi, społecznymi, psychologicznymi, które stanowić będą podłoże intelektualne monstrum XX wieku, faszyzmu. „odrzucenie rozumu, wrogość wobec ideałów kultury śródziemnomorskiej [...] zmierza do tego, aby jednostka na łeb, na szyję rzuciła się w odmęty i mistycznie zagubiła się w powszechnym bycie, stanowią jakieś pendant do faszystowskiej mistyki krwi i ziemi, uwielbienia mrocznej, starogermańskiej mitologii, do faszystowskiego kultu wodza i narodu. Średniowiecze, o którym mówi tyle Naphta nie jest ziemią obiecaną dla romantyków, jest ono symbolem nawrotu barbarzyństwa [...] średniowieczem mas opętanych przez

39 T. Mann, Czarodziejska Góra, t. 2, s. 117.

$40 \quad$ N. Honsza, Tomasz Mann - arystokrata ducha, Wrocław 1993, s. 68. 
demony pogardy, nienawiści i zbrodni, ślepo uległych irracjonalnym namiętnościom, dającym się wodzić złowrogim szarlatanom" ", pisze C. Rowiński. Naphta wyznaje apologię wojny, terroru, gwałtu, przemocy i bezprawia; grzmi przeciwko burżuazyjno - kapitalistycznej konkretyzacji rzeczywistości; przejawia poglądy ugrupowania rewolucyjnych konserwatystów, którzy byli przez długi okres czasu sojusznikami faszystów. Podglądy Naphty stanowią eklektyczny zlepek najmętniejszych pierwowzorów intelektualnych epoki. „Być może jest w tym nieco racji, ale czyż sama ideologia faszystowska nie była ściekiem, do którego spływały wszystkie brudy rozkładającego się świata mieszczańskiego?"42, pyta retorycznie C. Rowiński. Zatem Naphta przejawia nie tylko wrogość wobec tradycji humanistycznej, przepowiadając jej rychły upadek, ale reprezentuje rodzącą się doktrynę faszyzmu. I w tym starciu stanowisko T. Manna w stosunku do światopoglądu niedoszłego jezuity jest jednoznaczne. Możliwość ośmieszania i ironizowania na temat naiwnego, słabego, bezradnego, humanistycznego szermierza, Settembriniego, to jedno, ale daleko widzący autor Czarodziejskiej Góry swym przenikliwym umysłem dostrzega kiełkujące niebezpieczeństwo w doktrynie społecznej Naphty i w jego nieprzeniknionym, wszechogarniającym, porywającym z wielką lekkością innych „społeczników” radykalizmie. W sporze tym T. Mann ukazuje pierwsze i znaczące przejawy faszyzmu: demoniczność i zbrodniczą przewrotność, obskurantyzm oraz wieloznaczność. W liście do Alberta Einsteina z dnia 15 maja 1933 roku T. Mann pisze: „ten stan nie odpowiada zupełnie mojej naturze, zdeterminowanej przez Goethowsko-reprezentatywne elementy tradycji i bynajmniej nie stworzonej do martyrologii. [...] Cała ta niemiecka rewolucja jest z gruntu zła i fałszywa. [...] W całej swej istocie jest nie odrodzeniem - cokolwiek by o tym mówili i wrzeszczeli jej wyznawcy - lecz nienawiścią, zemstą, pospolitą żądzą mordu i drobnomieszczańską małostkowością" 43 .

Bohater Czarodziejskiej Góry z niecierpliwością oczekuje powrotu „nowego średniowiecza", które oparte będzie o zasady i normy dawnego Państwa Bożego; jednak do powstania tego państwa dopuszczone zostają metody dopiero, co kiełkujące na początku XX wieku, oparte o radykalną ideologią i konsekwentny terror. W przedstawionym światopoglądzie Naphty doszukać się można myśli, które już pojawiły się wcześniej w filozofii niemieckiej. T. Mann dokonał doskonałego przetworzenia myśli i skompensował je w jednym bohaterze, ukazując tym samym niebezpieczeństwo rodzących się eks-

${ }^{41}$ C. Rowiński, Spór Naphty z Settembrinim, s. 313.

42 Tamże, s. 315.

43 T. Mann, Listy 1889-1936, Warszawa 1966, s. 437. 
tremalnych doktryn społecznych. Pragnienie powrotu do „nowego średniowiecza", które oświetli mroki współczesnej myśli humanistycznooświeceniowej stanowić może nawiązanie do romantycznego filozofa, G. F. von Hardenberga, zwanego Novalisem. Jednakże, T. Mann nie dokonuje tutaj skrupulatnej analizy i przełożenia tejże filozofii XIX wieku na wiek XX, lecz skupia się na niebezpiecznie prostym (jak określił Schulz) eseju Chrześcijaństwo, czyli Europa. Tekst wzbudził ogromne kontrowersje ówczesnego świata intelektualnego, który musiał zwrócił się do najwybitniejszego niemieckiego poety Johanna Wolfganga Goethego z zapytaniem, czy ów esej należy wydrukować. Nawet tak tolerancyjny krytyk, jakim był romantyczny mistrz klasycyzmu, odradzał tejże publikacji. Dogłębne analizy filozofii kontrowersyjnego romantyka mają miejsce dopiero w latach nam współczesnych. Dotychczas jeszcze podchodzi się z wielką rezerwą i niezrozumieniem do dzieła, które w swojej treści przekazuje wartościową myśl i stanowić ma syntezę nowego i starego świata w imię i za sprawą miłości. A główną konstatacją jest próba odnalezienia sposobu na przezwyciężenie dwóch wielkich zasad świata nowoczesnego: rewolucji i reakcji ${ }^{44}$. W XIX wieku esej, który stanowi jeden z największych tekstów kultury europejskiej, został odczytany w sposób bezpośredni i zdroworozsądkowy, bez doszukiwania się w nim głębszych treści i znaczącej analizy, która doprowadzić mogła do docenienia już dwa wieki wcześniej wartości i wysokiego poziomu tekstu. „Szyderstwem było jego odczytanie w 1826 r. jako manifestu ideowego Świętego Przymierza, szyderstwem jego zawłaszczenie przez propagandę Rzeszy Małoniemieckiej w 1871 r., szyderstwem jego wykorzystanie jako profetycznej wizji tysiącletniej rzeszy Adolfa Hitlera [...]" ${ }^{45}$; pisze Wojciech Kunicki. Podobnie ocenia Honorata Jakuszko, „stara się wykazać, że te zarzuty stosują się do pewnych przejaskrawionych, skostniałych dogmatycznie konkretyzacji zasady chrześcijańskiej, nie zaś ducha chrześcijaństwa, dla którego rozwoju pomocne, a nawet niezbędne są takie krytyki wnoszone przez świadomość reformatorską, heretycką, czy nazywającą siebie ateistyczną albo antychrześcijańską" ${ }^{46}$. Dotychczas jednak nieodkryta do końca filozofia Novalisa interpretowana była w sposób prosty i niezupełny. Jeśli inspiracją dla T. Manna był esej Chrześcijaństwo, czyli Europa, to należy tutaj podejść do odczytanych poglądów nie w świetle badań współczesnych, lecz w świetle, w jakim wtedy odczytywano to dzieło. Nie można z cała pewnością wykluczyć, że T. Mann

${ }^{44}$ W. Kunicki, Wstęp, w: Novalis, Henryk von Ofterdingen, Wrocław-Warszawa-Kraków 2003, s. LI.

45 Tamże, s. LV.

46 H. Jakuszko, Novalis: chrześcijaństwo w strukturze czasu historycznego, „Archiwum Historii Filozofii i Myśli Społecznej” 1990, t. 35, s. 69. 
odczytał ten tekst w sposób identyczny, jak jego mistrz liryczny, Johann Wolfgang Goethe, nie dostrzegając w nim prawdziwego przesłania. Nie można jednak wykluczyć również, że jest to sprytny zabieg, by ukazać przenikliwemu czytelnikowi niebezpieczeństwo wyznawania poglądów, których się nie rozumie, nie zna ich prawdziwej treści, a wyznaje jako prawdziwe myśli. Tak rodzi się ideologia, która w wieku XX ukazała swoje najciemniejsze strony i krwawe skutki. Być może T. Mann tylko przypisał Naphcie poglądy, wyrażone przez Novalisa (tak jak one bezpośrednio brzmią; powyrywane myśli z całościowego kontekstu), by ukazać radykalizm, do jakiego może prowadzić proste odczytanie eseju.

Novalis został odrzucony przez wielkie autorytety, na których ciążyło zbyt silnie oświeceniowe wychowanie i zbyt ogromne rozmiłowanie klasycyzmu w autorytecie świata starożytnego, by móc przyjąć apologię chrześcijaństwa. „[...] Goethe znieść tego nie był w stanie, odradzając publikację tekstu, którego poetyki nie zrozumiał, bo najprawdopodobniej zrozumieć nie mógł, choć wyrastała ona z bardzo podobnych przesłanek, co historiozofia Schillera lub jego samego wyobrażenia o dziejach, które od czasu do czasu winniśmy pisać na nowo" ${ }^{47}$; pisze W. Kunicki. Novalis poszukuje istotnego opracowania Nowego Testamentu, kierując się w stronę przyszłości, tworząc nową koncepcję świata i człowieczeństwa, dokonując anihilacji teraźniejszości. „[...] pisał F. Schlegel do Novalisa: «Masz wybór, albo być ostatnim Chrystusem, Brutusem starej religii, albo Chrystusem nowej ewangelii»" ${ }^{48}$; cytuje H. Jakuszko. Dla romantycznego filozofa stanowisko oświeceniowe nie oczekuje pasywnie realizacji ideału przez Boga, lecz stara się dokonać przemiany świata w teraźniejszości (zrozumiała staje się zatem walka humanistySettembriniego z Naphtą o nadanie wartości procesowi rozwoju i postępu). Również wbrew tym myślicielom podkreśla skuteczność średniowiecznej formy państwowej, jakim była monarchia, przeciwstawiając ją oświeceniowej demagogii na cześć idei republikańskiej. „Były to piękne, świetlane czasy, kiedy Europa była krajem chrześcijańskim, kiedy j e d e n chrześcijański lud zamieszkiwał tę część świata, nadając jej ludzki kształt; j e d e n wielki wspólny interes łączył najbardziej odległe prowincje tego rozległego duchowego państwa. Nie mając wielkich świeckich posiadłości, j e d e n zwierzchnik kierował i jednoczył wielkie siły polityczne" ${ }^{\prime 9}$; pisze Novalis i dodaje „ale ludzkość nie była jeszcze dostatecznie dojrzała i ukształtowana, by mieć tak

47 W. Kunicki, Wstęp, s. XLIX.

48 H. Jakuszko, Novalis: chrześcijaństwo w strukturze czasu historycznego, s. 55.

49 Novalis, Chiristenheit oder Europa; cyt. za: H. Jakuszko, Novalis: chrześcijaństwo w strukturze czasu historycznego, s. 60. 
wspaniałe państwo" ${ }^{50}$. Uwidocznione zostaje tutaj wyraźne podobieństwo między myślami Novalisa (oczywiście w prostym odczytaniu i bez całościowego kontekstu) a poglądami wyrażonymi przez bohatera Czarodziejskiej Góry. Naphta jest gorliwym przeciwnikiem koncepcji humanistycznych i oświeceniowych, widząc w doktrynie chrześcijańskiej przyszłość wszelkiej cywilizacji i kultury; jest wielkim zwolennikiem napisania dziejów na nowo, wzorując się na „wiekach średnich” oraz oddania władzy przedstawicielom Kościoła, by określali skrupulatnie normy i prawa oraz narzucali jedyny, prawidłowy sposób myślenia. Jak pisał Novalis, „[zabraniał Kościół] śmiałym myślicielom publicznie twierdzić, iż Ziemia jest tylko znaczącą wędrowną gwiazdą, dobrze bowiem wiedział, ze wraz z szacunkiem dla swych siedzib i swej ojczyzny ziemskiej ludzie straciliby również poważanie dla swej ojczyzny niebiańskiej" ${ }^{51}$. Ponadto warto wspomnieć jeszcze o tym, że historia dla Novalisa charakteryzowała się przemiennością przeciwnych ruchów, a zatem luteranizm sprowokował pojawienie się dziejowego przeciwnika, którym był zakon jezuitów. To nawiązanie (Naphta jest jezuitą) jest nieprzypadkowe. Novalis narzuca kontrreformatorom zadanie ponownego zjednoczenia ludzkości wokół idei katolicyzmu, takie samo, które w radykalnych hasłach wypowiada Naphta.

Jedną z takich może się wydawać myśl Naphty, że „filozofia państwa” Hegla jest w sensie religijnym na wskroś przeniknięta katolicyzmem (nie kościelno-dogmatycznym, bo Hegel był protestantem). Dla Hegla państwo nie jest przypadkowym wytworem, lecz nieuniknioną, najwyższą formą ustroju społeczeństwa; stanowi ono postać ducha obiektywnego. Za Arystotelesem można określić w odniesieniu do treści „filozofii ducha” jednostkę jako zoon politikon, która urzeczywistnia swoje jestestwo dopiero w społeczeństwie. Hegel widzi to spełnienie w wyższej formie społeczeństwa, w państwie (społeczeństwo jest wytworem naturalnym, natomiast państwo mające charakter ducha powstaje z czynników ideowych). Człowiek dopiero w ramach państwa otrzymuje swoją realność i wartość moralną. Dla Naphty taka koncepcja polityczności pozostaje w zgodzie z doktryną Kościoła katolickiego. „[...] Albowiem pojęcie polityczności jest psychologicznie sprzęgnięte z pojęciem katolicyzmu, tworzą one jedną kategorię, obejmującą wszystko, co obiektywne, czynne, co ma zdolność urzeczywistnienia i oddziaływania na zewnątrz" ${ }^{2}$, precyzuje Naphta.

Tamże, s. 62.

Novalis, Chiristenheit oder Europa, cyt. za: W. Kunicki, Wstęp, s. XLIX.

Tamże, s. 100. 
Filozofia Hegla, która do dziś kojarzona jest z lewicą (doktryną Marksa i Engelsa), posiadała także swój odłam prawicowy (tzw. szkoła staroheglowska), która wtapia się w pogląd Naphty o zgodności filozofii Heglowskiej z chrześcijaństwem. Przejawiała ona także jego konserwatywne doktryny i nie występowała przeciw tradycjonalistycznym koncepcjom teologicznym, których powrotu Naphta wręcz oczekuje. „Wersja Heglowska wieści o śmierci Boga ma sens jednoznacznie chrześcijański, jakkolwiek kontekst tej myśli, a mianowicie majestatyczny model samorozwoju i samorozumienia Boga, przypomina raczej gnozę, [...] Bóg sam przechodzi przesmykiem śmierci z epoki Syna do epoki Ducha, idzie z innobytu, alienacji względem samego siebie, do pełnej samowiedzy. Śmierć Chrystusa jest negacja negacji: w Jezusie Bóg z miłości i dobrowolnie przyjmuje na siebie śmierć - która w swej istocie jest negacją wolności - i przez to pokonuje ją. [...] Hegel widzi w krzyżu dopełnienie Bożego wcielenia - Bóg wziął tu na siebie całe brzemię ludzkiej skończoności [...] w rozumieniu Hegla Bóg umarł z miłości" ${ }^{53}$, pisze ks. Tomás Halík. Dla Hegla religia osiągała postać absolutnego ducha, a poziom wyobrażeń tworzył ewolucyjną konstrukcję; etapy rozwoju, które łączyły się w szereg dziejowy. Tą ostatnią fazą, która przewyższa wszelką religię żydowską, grecką, rzymską; jest religia prawdy, wolności i ducha, czyli chrześcijanizm.

W ten sposób zinterpretowany Hegel może stanowić podstawę intelektualną dla poglądów jezuity Czarodziejskiej Góry, który poszukuje usprawiedliwienia swego radykalizmu i absolutyzacji poglądów, a filozofia ducha pozwala mu na związek katolicyzmu z doktryną społeczną. Sam Hegel pisał, że Chrystus, który przybył do Palestyny, nie chciał narzucać komukolwiek swoich dogmatów, ale uwarunkowania kulturowe wymusiły na nim taką formę nauki, by zapewnić posłuch wśród Żydów. Naphta również nie interpretuje zasad chrześcijańskich jako surowych dogmatów, do których przymusza się społeczeństwo i narzuca się im odpowiedni sposób życia. Zapewne zgodziłby się z Heglowskim stwierdzeniem, że Żydzi sami swoim zachowaniem wymusili taką formę przedłożenia im nauki Chrystusowej. „Cuda i tym podobne nie miały służyć uzasadnieniu nauk, które mogą się opierać na faktach, a jedynie wzbudzeniu, dzięki tym zdumiewającym zjawiskom, uwagi ludu, głuchego na sprawę moralności” ${ }^{54}$, pisze Hegel.

Meritum stanowić będzie stan idealny, związany z transcendencją Bożą. W świetle państwa heglowskiego, bez którego człowiek nie posiada swojej realności, przełożeniem na doktrynę kościelną będzie określenie człowieka,

53 T. Halík, Świadkowie Bożej nieobecności, „Tygodnik Powszechny” 2003, nr 16, s. 5.

54 G. W. F. Hegel, Pozytywność religii chrześcijańskiej, w: Pisma wczesne z filozofii religii, przeł. G. Sowiński, Kraków 1999, s. 159, 160. 
jako niedoskonałości, która musi przyjąć proponowaną eschatologię, by móc dotknąć tego co najwyższe, Boga (po heglowsku: ducha obiektywnego i absolutnego). „Absolutnie uważanie jej za jedyny stan, za boski, ostateczny stan ducha, dumą będąc najmocniejszą, zarazem też podłych, ograniczonych z nas bogów czyni - śmiertelnych na wieki! Skoro zaś jako ludzie na planecie wyznamy z pokorą, żeśmy nie cali jeszcze w sobie, nie absolutni, że eschatologia wyciąga ku nam ramiona, wnet tą pokorą unieśmiertelnieni rośniemy w prawdziwych bogów, w takich o jakich śni się Novalisowi, kiedy mówi: Gott will Götter [Bóg pragnie bogów]" ${ }^{55}$, pisze w kontekście heglizmu Zygmunt Krasiński.

T. Mann nie traktuje z pobłażliwością bohatera Czarodziejskiej Góry, jak to czynił z jego oponentem Settembrinim. Humaniście nie szczędził ciężkich słów ironii, ośmieszał często słowami Naphty jego poglądy, nie zgadzał się na dogmatyczny i apodyktyczny racjonalizm. W takiej postawie dostrzegł niebezpieczeństwo i taki świat Settembriniego oskarżał o tchórzostwo i zezwolenie na zadomowienie się ideologii faszystowskiej. Settembriniego jednak traktuje on z sympatią i obdarza go ciepłym uczuciem. T. Mann dostrzega bowiem na innym piętrze poznania intelektualnego możliwość skorygowania błędów racjonalizmu i humanizmu przedwojennego i dostosowanie go do nowych warunków społeczno-politycznych epoki. W humanizmie kryje się tajemnica prawdziwego człowieczeństwa, w humanizmie, któremu granice wyznacza klasyczne, mannowskie usposobienie, zarazem pozbawione swoich wad i niedoskonałości XIX wieku i pierwszej połowy XX wieku. Znamienny jest stosunek do Naphty, który budzi w autorze Czarodziejskiej Góry zgrozę i przerażenie. T. Mann zarysowuje postać jezuity, nawet zewnętrznie przypisując mu atrybuty szatana. Postać Naphty od pierwszych stronnic wywołuje w czytelniku głęboką odrazę i sprzeciw; wyraża ona coś nieludzkiego, pewną demoniczność związaną ze zbrodniczą przewrotnością. W tej doktrynie, której zezwolił na pojawienie się zadufany w sobie, racjonalny świat XX wieku, dostrzega T. Mann największe niebezpieczeństwo. W liście do Ernesta Bertrama z dnia 30 lipca 1934 pisze, „Czy Pan zaczął już widzieć? Nie, ponieważ krwawe ręce zasłaniają Panu oczy, a Pan chętnie poddaje się tej «osłonie». Niemieccy intelektualiści - proszę mi wybaczyć ten termin, użyty w znaczeniu czysto rzeczowym - zaczną widzieć ostatni, zbyt głęboko bowiem, zbyt haniebnie zaangażowali się i obnażyli" ${ }^{\prime 5}$.

A G N I E S Z K A T U R O Ń

55 Z. Krasiński, Listy do Augusta Cieszkowskiego, Edwarda Jaroszyńskiego, Bronisława Trentowskiego, t. 1, Warszawa 1988, s. 125.

56 T. Mann, Listy 1889-1936, s. 480. 


\section{Abstract}

Thomas Mann's thoughts on the tragic conception of the artist's fate focus on the function the artist should fulfill in the society. A blessed and free-setting art will be always essential for a human being, because man could truly discover a human in himself through the literature.

Thomas Mann, as the German intellectual, had to bring himself face to face with the whole social and political issues after the lost war and take a position on the arising fascist ideology, which he considered as an enormous danger.

The whole reflection mentioned above bases on the period of writing The Magic Mountain, which was the answer to the question of the right way that young man (German especially) should follow in the $20^{\text {th }}$ century and stand he should take those which develop from the dehumanized forms. As the result, those forms constrained the human being and led to a constrait of the nations.

One of the characters of The Magic Mountain, a would-be Jesuit Naphta, becomes the symbol of the perils, of which Thomas Mann forewarns the European civilization. 